\title{
Relationship of 2D Affinity to T Cell Functional Outcomes
}

\author{
Elizabeth M. Kolawole ${ }^{\mathbb{D}}$, Tracey J. Lamb and Brian D. Evavold * \\ Department of Pathology, University of Utah, 15 N Medical Drive, Salt Lake City, UT 84112, USA; \\ emkolawole@path.utah.edu (E.M.K.); tracey.lamb@path.utah.edu (T.J.L.) \\ * Correspondence: brian.evavold@path.utah.edu
}

\begin{abstract}
T}$ cells are critical for a functioning adaptive immune response and a strong correlation exists between $\mathrm{T}$ cell responses and $\mathrm{T}$ cell receptor (TCR): peptide-loaded MHC (pMHC) binding. Studies that utilize pMHC tetramer, multimers, and assays of three-dimensional (3D) affinity have provided advancements in our understanding of $\mathrm{T}$ cell responses across different diseases. However, these technologies focus on higher affinity and avidity $\mathrm{T}$ cells while missing the lower affinity responders. Lower affinity TCRs in expanded polyclonal populations almost always constitute a significant proportion of the response with cells mediating different effector functions associated with variation in the proportion of high and low affinity $\mathrm{T}$ cells. Since lower affinity $\mathrm{T}$ cells expand and are functional, a fully inclusive view of $\mathrm{T}$ cell responses is required to accurately interpret the role of affinity for adaptive $\mathrm{T}$ cell immunity. For example, low affinity $\mathrm{T}$ cells are capable of inducing autoimmune disease and $\mathrm{T}$ cells with an intermediate affinity have been shown to exhibit an optimal anti-tumor response. Here, we focus on how affinity of the TCR may relate to T cell phenotype and provide examples where 2D affinity influences functional outcomes.
\end{abstract}

Keywords: pMHC; TCR; affinity; bond lifetime; T cells; 2D kinetics

\section{Introduction}

Recognition of pMHC by TCR is the initial trigger for activation of T cells and provides a gateway to the adaptive immune response. The affinity of TCR:pMHC interactions is an important initial regulatory parameter in activation. Although the distal role of $\mathrm{T}$ cells in the outcome of the immune response is widely investigated, fewer studies focus on the most proximal, engagement of TCR with pMHC. The bond between PMHC and TCR is often described as being relatively weak [1,2] in terms of 3D affinity and compared to antibodies [3-5], yet TCR:pMHC interactions are highly sensitive [6] with T cells responding to as few as 1-10 pMHCs on an antigen presenting cell [7-9]. This interaction is also decidedly specific [10] with the ability to differentiate single amino acid substitutions in peptide sequences that are then translated into differential phenotypic responses [11]. This sensitivity, specificity, and the extent to which a naïve T cell receives stimulation via the TCR contributes to the activation status and phenotype of that cell. In this review, we discuss the emerging body of work illustrating the significance of TCR two-dimensional affinity for pMHC (which is not to be confused with TCR avidity for $\mathrm{pMHC}$ ) in the initiation and dissemination of $\mathrm{T}$ cell signaling during attack of invading pathogens and autoimmune conditions.

\section{The Affinity Measurements of TCR}

The initial development of the $\mathrm{T}$ cell repertoire in the thymus results from the combination of both positive and negative selection to create a T cell population that is MHC restricted [12-14]. In a 
polyclonal response any one epitope can be recognized by $\mathrm{T}$ cells with differing affinities. The affinity of TCR for any particular PMHC can be measured in a number of different ways.

\subsection{D Methods of Measuring Affinity}

Surface plasmon resonance (SPR) provides a method for determining receptor-ligand affinity of purified proteins in a three-dimensional (3D) environment, whereby the purified mobile pMHC flows across purified immobilized TCR (Figure 1) yeilding an affinity measurement between TCR and cognate pMHC in the range of 1-100 $\mu \mathrm{M}$ [15-30]. This system, while deriving TCR:pMHC affinity for defined antigens does not always capture the full dynamic range of antigen specific $T$ cells missing responses dominated by lower affinity TCRs that occur in autoimmune disease and the immune response to cancer [23]. Furthermore, these types of analyses, while carried out using purified proteins (Figure 1a), also lack any localized influence provided by the complex membrane environment. In the case of membrane embedded proteins their interactions are constrained to fewer degrees of freedom and are governed by two dimensional (2D) parameters. Therefore, SPR allows for the analysis of receptor-ligand affinity in a reductionist format with purified proteins at the cost of accounting for the native cellular membrane milieu and any influence bestowed on TCR:pMHC interactions. A correlation between 3D affinity and T cell function can exist [31-34], but the 3D measurements do not changes in peptide [17,35-37]. Furthermore, SPR requires production of multiple purified TCRs to fully capture the breath of affinities present during a polyclonal immune response. Thus, measurements of TCR affinity in 3D may differ from biological responses [16-19,24,28,30,35,38,39].
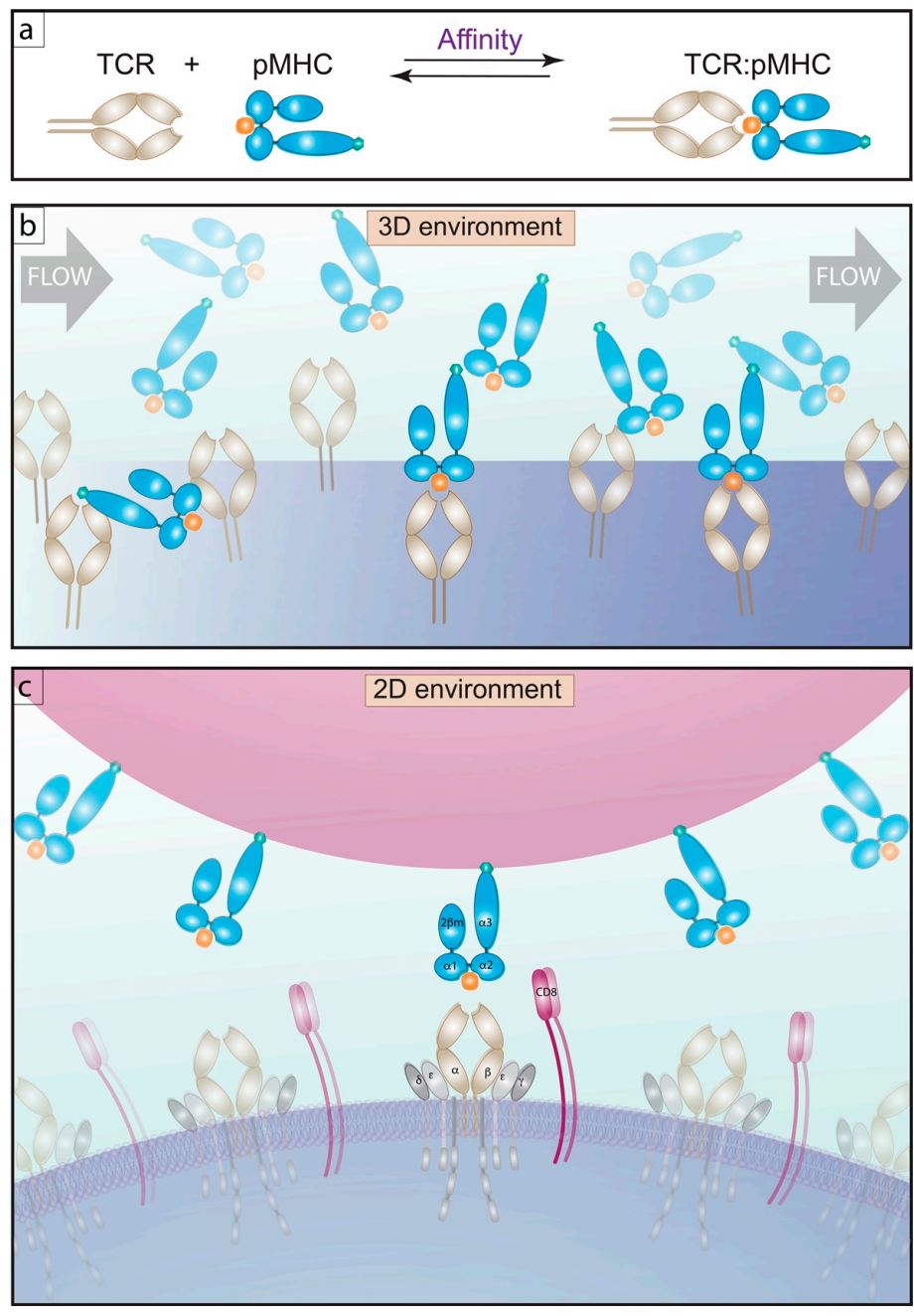

Figure 1. T cell affinity for $\mathrm{pMHC}, 3 \mathrm{D}$ versus a $2 \mathrm{D}$ environment. (a) schematic of an affinity reaction. 
(b) 3D affinity measurements by SPR, demonstrates soluble pMHC flowing over TCR bound to a sensor. Beneath this surface a detector records the change of resonance angle, giving a read out of affinity as the number of molecules per volume, $\mu \mathrm{M}^{-1}$. (c) $2 \mathrm{D}$ affinity measurements by 2D-MP show the interaction of TCR embedded in live T cells interacting with pMHC bound to surrogate APC's in the form of red blood cells (RBCs), these two cells are mechanically brought into contact and adhesion frequency is measured. The 2D affinity is read out as the number of molecules per area, $\mu \mathrm{m}^{4}$.

\subsection{D Methods of Measuring Affinity}

2D-based affinity measurements such as fluorescence based methods fluorescence recovery after photobleaching (FRAP) [40,41] and fluorescence resonance energy transfer (FRET) [42] (which are discussed elsewhere) [43,44] and the 2D micropipette adhesion frequency assay (2D-MP) [35,45-47] (Figure 1c) have advantages to measure both receptor and ligand as embedded within membranes. This allows for the investigation into how alteration of TCR affinity for pMHC operates in the context of the organization of the plasma membrane complete with CD3 proteins, co-receptor, Lck, lipid raft, actin cytoskeleton, and other proteins $[35,42,48]$. By nature, 3D affinity cannot fully replicate the biology of this interaction. This is perhaps best exemplified in the OT-I receptor transgenic altered peptide ligand (APL) system. Huang et al. analyzed six OT-I APLs which elicit varying degrees of immune activation and found direct correlates between varying 2D affinity $\left(\mu \mathrm{m}^{4}\right)$ and on-rates $\left(\mu \mathrm{m}^{4} \mathrm{~s}^{-1}\right)$. In contrast, the $3 \mathrm{D}$ affinity $\left(\mathrm{uM}^{-1}\right)$ and $3 \mathrm{D}$ on-rate $\left(\mathrm{uM}^{-1} \mathrm{~s}^{-1}\right)$ did not equate to response magnitude [35]. Furthermore, 2D kinetic rates were more sensitive than their 3D counterparts. This represented a 1000-fold change for 2D affinity and an almost 10,000-fold change in 2D on-rate compared with a $\sim 15$-fold change in 3D affinity and $<10$-fold change in 3D on-rate. In addition, 2D assays can measure affinity for ligands such as antagonists and self-epitopes involved in positive selection of thymocytes that are not easily detected by tetramer and 3D-based assays. Therefore, the increased sensitivity of 2D as compared to $3 \mathrm{D}$ is a clear advantage to $2 \mathrm{D}$ assays.

\section{Are Lower Affinity T Cells Real?}

\subsection{Low Sensitivity Techniques}

Much of what we know about the frequency and response of antigen reactive $\mathrm{T}$ cells is limited by the methods of detection. Enumeration of antigen-reactive T cells through the use of $\mathrm{pMHCI}$ and pMHCII tetramers and multimers (oligomers) has become the standard procedure due to increased reagent availability and convenience of flow cytometry-based analysis [49-52]. Although tetramer staining does not always reflect 3D affinity measurements, particularly in tumor and autoimmune models, the use of these highly valued techniques has shown a correlation with the number of cells identified by tetramer and cytokine production $[23,53]$. This begs the question as to the importance of the lower affinity $\mathrm{T}$ cells identified by $2 \mathrm{D}$ analyses.

Upon examination of differences in how these two different technologies measure T cell reactivity, it can be justified that lower affinity $\mathrm{T}$ cells will not be detected by tetramer and oligomer technologies for the following reasons. Firstly, tetramer technology is based on enhancing the TCR avidity by providing multivalent interactions [52,54-60]. The chemical definition of affinity is the equilibrium constant between on and off rates. Affinity in the context of immunological interactions can be described as the likelihood of bond formation between a single TCR:pMHC pairing as high affinity $\mathrm{T}$ cells have a high probability of bond formation compared to low affinity $\mathrm{T}$ cells, which have a low probability of forming bonds and propagating TCR signaling. Tetramers, however, measure the avidity of several bonds between multiple recombinant $\mathrm{pMHC}$ molecules. The monomeric binding of the first arm of pMHC in a tetramer to TCR increases stability of the complex and alters the kinetic rates to allow successive pMHC arms of the tetramer to bind [61]. This avidity interaction requires a minimum 
affinity for the first monomer to bind that will thereby underestimate the number of antigen reactivity cells $[16,62]$. Secondly, it is often assumed incorrectly that the intensity of tetramer staining equates with TCR affinity. While tetramer can identify the higher affinity $\mathrm{T}$ cells, often the intensity does not equate to TCR affinity $[16,61,63-66]$. Thirdly, TCR density can affect tetramer interaction $[55,67]$. This means that $\mathrm{T}$ cells that express a low density of TCRs would fail to stain with tetramers even if the TCR affinity is high. Lastly, it is difficult to simultaneously measure tetramer and intracellular cytokines by flow cytometry in response to antigen due to internalization of the TCR upon stimulation. This makes it challenging to attribute cytokine production solely to tetramer positive cells.

\subsection{Specificity with High Sensitivity by 2D-Micropipette}

The main discrepancy between tetramers and the frequency of antigen reactive $\mathrm{T}$ cells by 2D-based techniques lies in the sensitivity of these respective assays. Related to sensitivity is the requirement for specificity. In the case of tetramers, non-specific tetramers are often used to provide the background reactivity in the sample, although it seems this control is sometimes overlooked. Similarly, the 2D-micropipette measurements are routinely compared to other pMHC monomers as a control for specificity. In a polyclonal immune response, the 2D-micropipette has the sensitivity to derive affinity for single receptor-ligand interactions with affinities ranging anywhere from $10^{-1}$ to $10^{-7} \mu \mathrm{m}^{4}$. This sensitivity will detect T cells expressing lower amounts of TCR that may be missed by other methods, such as tetramer staining. For each model system and each set of experiments, $\mathrm{T}$ cells are tested to a range of pMHC-coated red blood cells (RBCs) concentrations. Those RBCs with the highest concentration of pMHC are able to detect the lowest affinity $\mathrm{T}$ cells and those with the lowest concentration are able to detect the highest affinity $\mathrm{T}$ cells. A T cell of interest is first aspirated onto a pipette with a pMHC-coated human RBC (hRBC) possessing a high density of monomer on an opposing pipette (Figure 2a). When binding occurs between the two opposing cells an adhesion frequency is calculated [68]. T cells are additionally probed with RBCs coated with antigen-irrelevant pMHC monomers (Figure $2 b$ ) and those devoid of pMHC (Figure 2c) to determine any rates of non-specific binding [63,69-71]. In the case of CD4+ T cells this control is often Class II invariant chain peptide (CLIP) as it is provided by the NIH tetramer core facility as the control for MHC class II tetramers due to the property that it binds to most MHC class II alleles. If binding with the high concentration of pMHC is $>80 \%$ the $\mathrm{T}$ cell is tested to a lower pMHC concentrations (Figure $2 \mathrm{~d}-\mathrm{f}$ ) until a binding frequency of $<80 \%$ is reached. Use of an adhesion frequency range of $10-80 \%$ allows for exclusion of the extreme limits of detection on any given RBC [35,69]. Adhesion frequency in conjunction with the density of TCR on the T cell and PMHC on the RBC allow for the calculation of 2D affinity (Box 1). Utilization of these controls has demonstrated that low affinity $\mathrm{T}$ cells, similar to higher affinity TCRs possess specificity to distinguish between the antigen-loaded pMHC of interest and control pMHC. 

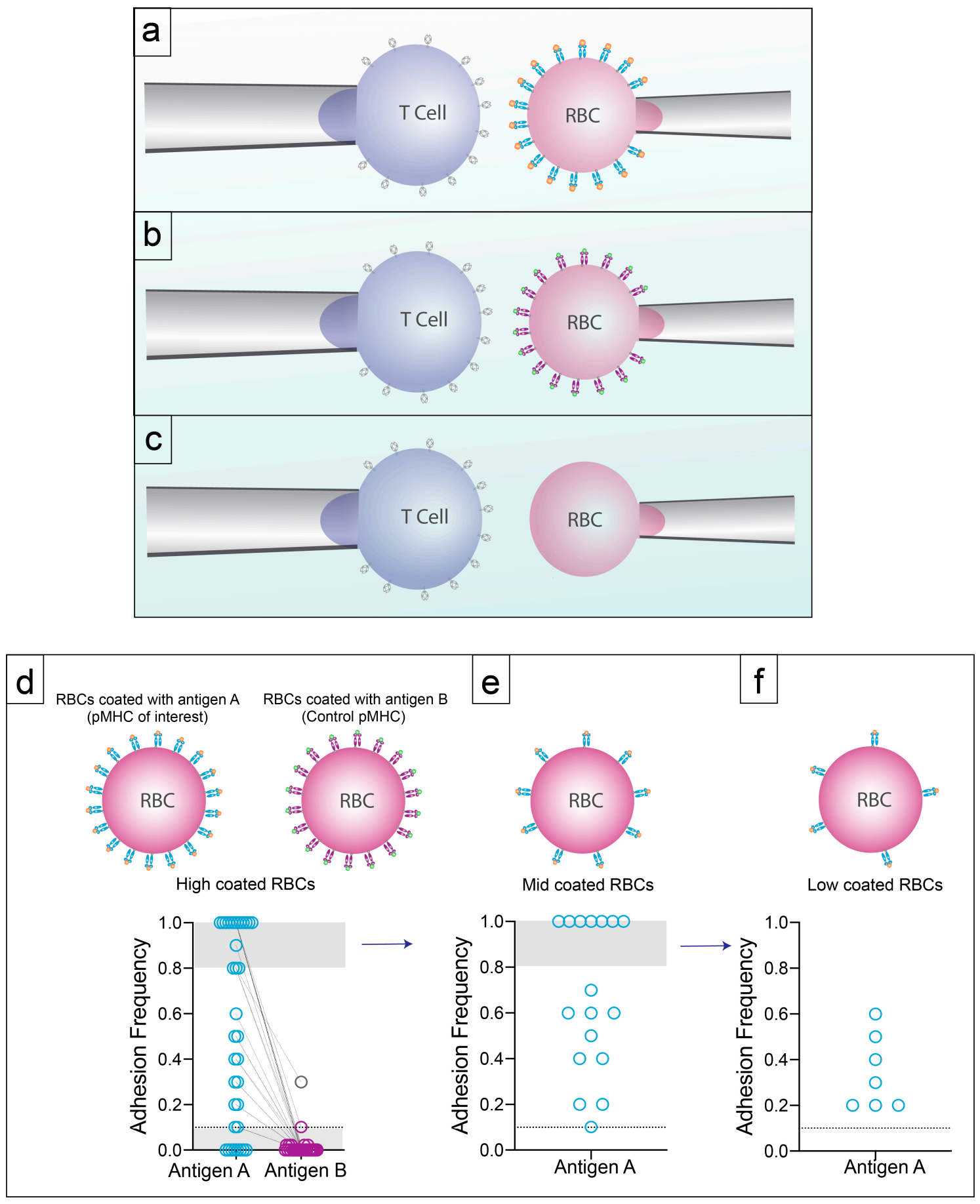

Figure 2. Controls and Specificity. (a) $\mathrm{T}$ cells of interested are aspirated onto a pipette with high density pMHC-coated hRBCs aspirated onto an opposing pipette. Cells are brought into contact using a piezoelectric actuator 50 times. (b) If binding is detected with pMHC of interest between the range of $10 \%$ and $80 \%$ the hRBC is switched out for a hRBC coated with an irrelevant pMHC to test specificity. (c) $\mathrm{T}$ cells tested to hRBCs without $\mathrm{pMHC}$ to test for non-specific binding between the $\mathrm{T}$ cell and non pMHC molecules on the hRBC. (d) Adhesion frequency of each cell tested to pMHC of interest and irrelevant pMHC. (e) If the pMHC of interest has an adhesion frequency of $>80 \%$ the hRBC is replaced with a hRBC coated with a lower pMHC density. (f) If using a lower pMHC density still yields an adhesion frequency of $>80 \%$ we continue to move to a lower pMHC density. Following this, $2 \mathrm{D}$ affinity can be calculated. 
Box 1. Defining TCR affinity for $\mathrm{pMHC}$.

In immunology, affinity is the probability of bond formation that can often times be a predictor of cell function or signal strength particularly when used in conjunction with bond lifetime. The affinity of TCR for pMHC (association constant $\left.K_{a}\right)$ is derived from the on/off rates $\left(K_{o n}\right)$ and $\left(K_{o f f}\right)$ of this interaction at equilibrium $[16,72]$. The effective $2 \mathrm{D}$ affinity is encompassed by the equation $A_{c} K_{a}=-\ln \left(1-P_{\mathrm{a}}\right) m_{\mathrm{r}} m_{\mathrm{l}}$, where the affinity $\left(K_{a}\right)$ and contact area $\left(A_{c}\right)$ between the T cell and surrogate APC (pMHC coated RBC) require quantification of the receptor density $\left(m_{\mathrm{r}}\right)$, the ligand density $\left(m_{\mathrm{l}}\right)$, and the frequency of adhesion $\left(P_{\mathrm{a}}\right)$ to be calculated.

Adhesion frequency $\left(P_{\mathrm{a}}\right)$ : When the two cells are brought into contact for an equilibrium contact time of two seconds, deformation and stretching of the highly flexibly RBC membrane upon separation of the two cells denotes an adhesion event and is recorded as a binding event and given a score of 1 . Lack of observed stretching denotes a non-binding event and is recorded as a score of 0 [68]. These set contact and retraction cycles (at equilibrium) are controlled by an electric piezo actuator for 50 contacts.

TCR receptor density $\left(m_{\mathrm{r}}\right)$ and pMHC RBC density $\left(m_{1}\right)$ : T cells and pMHC coated RBCs are stained with anti-TCR $\beta$ PE and anti-MHC class II PE antibodies, respectively, and run by flow cytometry. Densities of pMHC and TCR are calculated using BD QuantiBrite Beads. Molecules per area were calculated by dividing the number of TCR and pMHC per cell by the respective surface areas (hRBC $140 \mathrm{~mm}^{2}$, T cell during assay measured diameter of an individual $\mathrm{T}$ cell and the surface area equation of a sphere [35]). This measurement is of a single TCR-pMHC molecular interaction has long been expected as a predictor of T cell responses but this is not always the case [73]. Despite this definition of the reactants as purified proteins (Figure 1a), the affinity for T cells is more complex and often somewhat misapplied in immunology, especially to the TCR and its interaction with pMHC. To bypass some of the early difficulties in producing the purified proteins necessary to measure these interactions, "affinity" was often inferred indirectly by comparing functional readouts of different TCRs to different clones of the same antigen or through the use of altered peptide ligands (APLs) with different levels of functional potency that assumed different affinities for a single TCR clone $[37,74-76]$. The advent of pMHC tetramer technology also allowed a relatively easy measure of avidity to TCRs to pMHC by flow cytometry. While the highest affinity $\mathrm{T}$ cells are incorporated with tetramer staining, affinity is not an avidity interaction, nor is it the direct functional response often called strength of signal.

\section{Expansion and Frequency of Low Affinity CD4+ T Cells}

This specificity of low and high affinity TCRs, coupled with the sensitivity of the 2D-micropipette assay, provides a mechanism to define the frequency of antigen-reactive $\mathrm{T}$ cells directly ex vivo or following in vitro culture across the entire range of responding cells. For situations where higher affinity antigen-TCR:pMHC interactions are more prominent, tetramer and 2D-micropipette provide different views of the $\mathrm{T}$ cell response with tetramers underestimating the $\mathrm{T}$ cell response. One example during infection is the expanded mixed affinity profile of low and high affinity CD4+ T cells that respond to the dominant MHC-II epitope glycoprotein $(\mathrm{GP})_{66-77}$ of lymphocytic choriomeningitis virus (LCMV). At the peak of the immune response to LCMV, $10 \%$ of splenic CD4+ T cells react to $\mathrm{GP}_{66-77}$ by tetramer staining compared to $\sim 45 \%$ by $2 \mathrm{D}$-micropipette [69]. Self-reactive T cells often express TCRs of low affinity with most harboring TCRs with affinity too low to bind to tetramers $[49,51,55,62,67,77-80]$. Thus, when 2D-micropipette is used to look at antigen-reactivity of CD4+ T cells in autoimmune diseases such as the Experimental Autoimmune Encephalomyelitis (EAE) mouse model of Multiple Sclerosis (MS), the frequency of autoreactive CD4+ T cells is much higher than previously appreciated using tetramer staining. At peak disease, 2D micropipette detected $\sim 80 \% \mathrm{MOG}_{38-49}$ reactive CD4+ $\mathrm{T}$ cells in the CNS, $70 \%$ in the draining cervical lymph nodes and $\sim 15 \%$ in the spleen [81] compared to $4-8 \%$ in the CNS, and $<1 \%$ for both draining cervical lymph nodes and the spleen that was stained with $\mathrm{MOG}_{38-49}$ tetramer. Similarly, in diabetes analysis of the frequency of hybrid insulin peptide (HIP2.5)-reactive $\mathrm{T}$ cells by micropipette detected $\sim 40 \%$ antigen reactivity in pancreatic islets of diabetic NOD mice compared to $\sim 4 \%$ by tetramer [71]. Also for the diabetogenic insulin antigen (InsB ${ }_{9-23}$ ), the frequency of $\mathrm{CD} 4+\mathrm{T}$ cells was below the limit of detection for tetramer, yet 2D-micropipette revealed $58 \%$ and $47 \%$ InsB $_{9-23}$-reactive $\mathrm{CD} 4+\mathrm{T}$ cells in the islets and spleen, respectively [82]. Use of 2D-micropipette to measure antigen-reactive $\mathrm{CD} 4+\mathrm{T}$ cells has thus begun to alter our understanding of disease progression during infection and autoimmunity by demonstrating that there is a much higher frequency of antigen specific CD4+ $\mathrm{T}$ cells than previously appreciated. 
Polyclonal 2D affinity is a functionally relevant metric. The low precursor frequency of antigen-reactive $T$ cells to any antigen dictates that all antigen-reactive cells identified, regardless of affinity, were detected in the assay because they underwent cell division and expanded in number. This is illustrated in the situation of T1D where HIP-reactive CD4+T cells are predominantly measured in the organ of relevance (the islets) but not in the spleen where their frequency is rare among all of the other $\mathrm{T}$ cell specificities [71]. Precursor frequency of quiescent peripheral T cells with lower or high affinity TCRs has been shown to influence the profile of activated T cells [83]. For example, naïve precursor frequencies of high affinity $\mathrm{T}$ cells identified by tetramers correlated with immunodominance of foreign antigen-specific CD4+ T cells as measured by tetramer following immunization. Of interest, enumeration of naïve precursor frequency and expanded $\mathrm{T}$ cells as measured by 2D-micropiette yields a more robust correlation owing to the inclusion of lower affinity antigen-reactive $\mathrm{T}$ cells that evade tetramer detection [84]. The 2D-micropipette data is supported by in vivo limiting dilution where the majority of antigen-reactive clones were low affinity and tetramer negative across several CD4+ $\mathrm{T}$ cell responses specific for influenza, LCMV, mycobacterium, flagellin, and myelin specific antigens demonstrating this broadly applicable principle [84].

\section{The Affinity of TCR for pMHC Modulates TCR-Derived Signals}

Data from the 2D-micropipette assay in a variety of systems have revealed that lower affinity cells not only expand, but can also dominate polyclonal $\mathrm{T}$ cell expansion in the majority of systems tested $[63,69,70,81,82,84-87]$. Thus, it is pertinent to consider the functional ramifications for a $T$ cell that becomes activated via a lower affinity TCR. Both lower affinity and higher affinity $\mathrm{T}$ cells can become activated to similar levels. This has been demonstrated in vitro by analysis of cultured polyclonal MOG $_{35-55}$-reactive or LCMV-reactive CD4+ T cells pulsed with $\mathrm{MOG}_{35-55}$ or $\mathrm{GP}_{61-80}$, respectively. After 1 week in culture both tetramer positive (higher affinity) and tetramer negative (lower affinity) produce similar levels of cytokines [63]. It has also been repeatedly shown that lower affinity $\mathrm{T}$ cells are capable of the host of effector functions needed for CD4+ T cell mediated autoimmune disease $[63,81]$.

Although possible differences in effector function between higher and lower affinity $\mathrm{T}$ cells may exist, this analysis is currently ongoing. What are the differences in the molecular interactions that govern the activation of $\mathrm{T}$ cells in lower affinity $\mathrm{T}$ cells compared to higher affinity TCRs? It is possible that $T$ cells with lower affinity TCRs simply have less of a chance of becoming activated due to potentially less contact time with a pMHC-displaying APC. Signaling from the TCR complex occurs in both higher and lower affinity $\mathrm{T}$ cells as evidenced by calcium flux [88,89] and zeta chain phosphorylation [90], albeit to potentially different levels. The early biochemical and kinetic parameters mediated by TCR:pMHC governs the extent of signal propagation. Thus, with high on-off rates on lower affinity $\mathrm{T}$ cells, TCRs may collectively have less time to propagate signals that emanate from both the TCR signaling complex and potentially through other molecules that are involved in $\mathrm{T}$ cell activation such as co-stimulatory molecules. Variation in signal strength can modulate the transcriptional pathways that are activated and potentially could lead to different functional properties. For example, self-reactive human CD4+ T cells expressing lower 2D affinity TCRs that do not stain well with tetramers formed unusual immunological synapses [86]. This may indicate a mechanism by which low accumulation of pMHC and TCR at the immune synapse of lower affinity T cells may influence function.

\section{Factors Influencing Expansion of Lower Affinity T Cells in Addition to 2D Affinity of the TCR for $\mathrm{pMHC}$}

Although detection of lower affinity CD4+ T cells occurs after expansion, a currently unknown factor is whether the affinity profile of $\mathrm{T}$ cells expanded from the precursor pool may be influenced by the type of antigen presenting cell (APC). It is possible that different APC subsets may influence the interaction with TCRs via differences in pMHC density and the amount and/or types of surface molecules that provide co-stimulatory signals. This could influence the breadth in the affinity of 
the responding $\mathrm{T}$ cells over and above TCR specificity by altering the strength of TCR signaling and TCR:pMHC bond lifetimes that emanate from high and low affinity TCRs upon ligation with pMHC.

\subsection{Differential Signaling from Co-Receptors}

While many studies focus on the interaction of TCR:pMHC (Figure 3a), the CD4 and CD8 co-receptors augment signaling downstream of TCR:pMHC by recruiting Lck to the CD3 signaling complex [91]. This alters the overall strength of binding [54] which could be important for lower affinity $T$ cells by providing compensatory interactions to increase strength of TCR signaling [77]. Both CD8 and $\mathrm{CD} 4$ co-receptors have relatively weak affinities for their respective MHC with the affinity of CD8 for MHC-I being higher than that of CD4 for MHC II by both 2D and 3D measures [91,92]. CD8 affinity for MHC as a confounding factor in identifying TCR affinity is controlled for in 2D-micropipette assays via the use of mutated pMHC-I monomers that cannot bind to CD8 (Figure 3a). One can also use intact pMHC and define the affinity of CD4 and CD8 co-receptors for MHC (Figure 3b), as well as probe the interaction of all three molecules termed "normalized adhesion bonds" (Figure 3c) [92-94] for a more complete analysis of these three interacting molecules directly ex vivo.
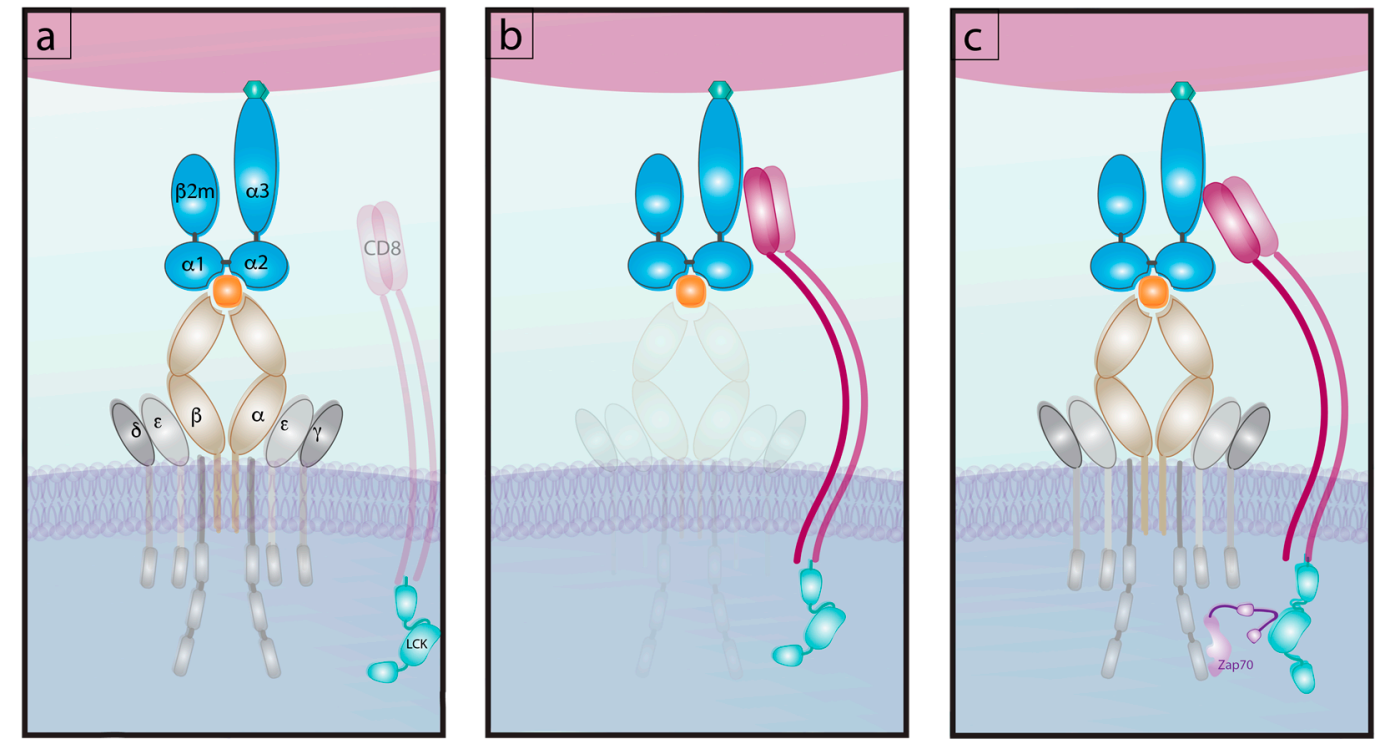

Figure 3. The interactions of pMHC with TCR and co-receptor. (a) TCR affinity interaction for pMHC excluding CD8 co-receptor. (b) CD8 Affinity interaction for pMHC excluding TCR. (c) The tri molecular interaction of TCR, CD8 and pMHC read out as "normalized adhesion bonds" and the engagement of Lck with Zap70.

\subsection{Bond Lifetime under Force: A Key Predictor of T Cell Function}

Once TCR engages with pMHC, the kinetic on- and off-rates can be influenced by a number of factors [95] that include 2D confinement time [96,97] and bond lifetime under force which can be measured by multiple techniques [98-100], which for TCR:pMHC include biomembrane force probe (BFP) [88], atomic force microscopy (AFM) [101-103], DNA tension sensor [90] and optical tweezer [104]. T cells apply force to the APC via the TCR:pMHC bond which leads to two types of effects. Catch bonds display increased bond lifetime as force is applied before reaching a peak level. For interactions exhibiting catch bond formation, force has been shown in multiple studies to peak at 10 pico Newtons ( $\mathrm{pN}$ ) for both CD4+ and CD8+ T cells [88,90,93,104-109]. Application of additional force after this level decreases the bond lifetime of a catch bond (Figure 4a). In contrast, application of force to a slip bond decreases the bond lifetime from the formation of the bond (Figure 4b). In terms of function, catch bonds are productive bonds giving rise to the longer lived bonds that mediate sustained calcium signaling and increased CD45 exclusion from TCR synapses, allowing TCR signaling 
to proceed $[88,107,109,110]$. The magnitude of bond lifetime has been shown to correlate with calcium release and the production of multipotent cytokine producing $\mathrm{T}$ cells, a hallmark of efficacious cytotoxic CD8+ T cells during infection [88,93].
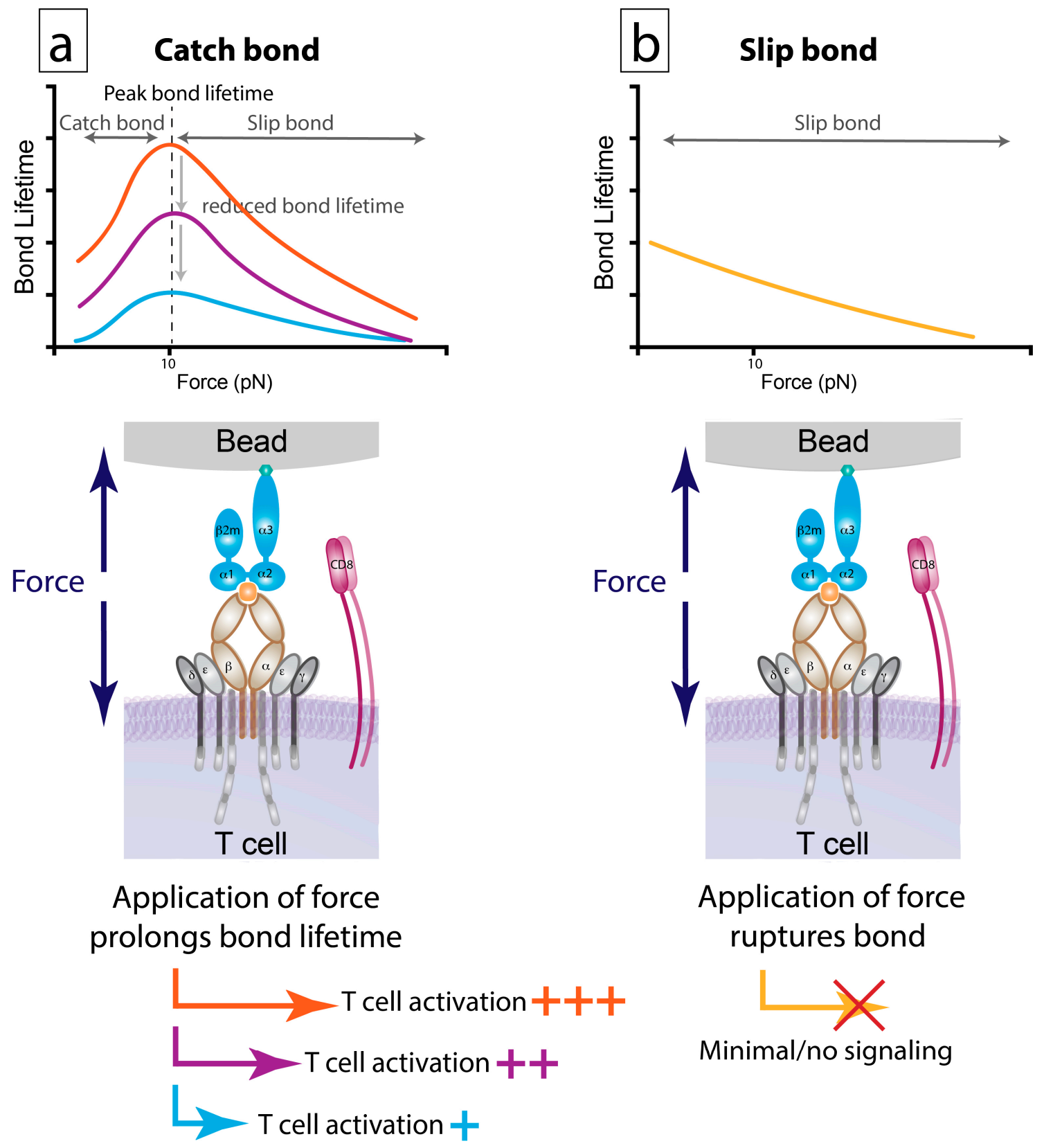

Figure 4. Catch versus slip bonds. (a) Catch bonds: As increasing amounts of force are applied to the TCR:pMHC complex bond lifetime increases until a pinnacle is reached. Continuing to increase force at this point results in decreases bond lifetime creating a catch bond. $10 \mathrm{pN}$ has been demonstrated to be peak force. Longer peak bond lifetimes result in increases $\mathrm{T}$ cell signaling. (b) A slip bond: as force is increased, bond lifetime decreases. Slip bonds generate minimal to no force.

Few studies have been carried on bond lifetimes under force since the measurements are currently limited to monoclonal systems due to the labor-intensive analysis of the single molecule interactions. However, some evidence indicates that bond lifetime may supersede the affinity measurements with respect to mediating T cell activation [107]. A recent study identified CD4+ and CD8+ T cells with TCRs that were high affinity and tetramer positive but failed to lead to T cell activation [110]. The failure 
of $\mathrm{T}$ cells harboring these high affinity TCRs occurred despite similar 3D affinity, tetramer staining, crystal structures, and T cell:APC dwell times when compared to T cells containing TCRs which did lead to activation. The key difference was that $\mathrm{T}$ cells with stimulatory TCRs formed a catch bond and the non-stimulatory TCR displayed slip bond characteristics. Together, these findings demonstrate that additional factors beyond TCR affinity may also impact $\mathrm{T}$ cell fate.

\section{Affinity Profile and CD4+ T Cell Effector Phenotypes}

T cells have a breadth of effector functions and phenotypic fates that can be adopted by $\mathrm{T}$ cell subsets. During an immune $\mathrm{T}$ cell response, a plethora of factors contribute to the transduction of a $\mathrm{T}$ cell signal into a biological response. The extent to which $\mathrm{T}$ cell effector function and memory are shaped occurs via modulation of signal duration [111], co-stimulation [112], macromolecular orientation [22,113], and the segregation of phosphatases such as CD45 from the T cell:APC synapse $[110,114]$. This concert of factors modulates acquisition of effector function in phenotypically different $T$ cell subsets [115] including regulatory mechanisms that dampen effector function. Given that the affinity of the TCRs on a T cell influence many of these factors, it follows that the affinity of a TCRs for pMHC on APCs [35] and the mechanical force that accompanies $\mathrm{T}$ cell activation $[88,116]$ could influence the development of different $\mathrm{T}$ cell phenotypes.

\subsection{T Effector Cells (Teff)}

The affinity profile of Teff is highly varied. It has long been believed that high affinity interactions between TCR:pMHC give rise to T cells with the ability to acquire effector properties and generate memory [1,117] but existing data does not support this belief. In particular, examination of CD4+ Teff in autoimmune disease is the best demonstration of the functional power of $\mathrm{T}$ cells harboring lower affinity TCRs. The need to recognize self-antigen to develop and survive positive selection without the immediate threat of autoimmune disease, coupled with the requirement to cross-react with foreign antigen to mount an effective immune response during infection, leads to the generation of a pool of peripheral T cells that by definition can react with self-protein. TCR affinity for foreign and self-antigens is likely a parameter for distinguishing foreign antigens and establishing self-tolerance [74]. Unlike populations of $\mathrm{T}$ cells reacting against foreign antigens derived during infection, negative selection of high affinity self-reactive TCRs in the thymus dictates that self-reactive $\mathrm{T}$ cells in general are dominated by $\mathrm{T}$ cells with low affinity TCRs for self.

To put this affinity profile in perspective, we have demonstrated that the self-reactive 2D2 TCR receptor transgenic mouse reactive for $\mathrm{MOG}_{35-55}$ [118], has an affinity $>10,000$ fold lower than the viral specific SMARTA TCR receptor transgenic mouse reactive for the $\mathrm{GP}_{61-80}$ epitope of LCMV. pMHC tetramer and multimers, therefore, do not readily detect antigen-reactive $\mathrm{T}$ cells that elicit a functional response $[63,64,81,82]$ but despite the exceedingly low affinity of 2D2 $\mathrm{T}$ cells, they proliferate to MOG peptide and, crucially, they induce the symptoms of EAE [85]. The efficacy of low affinity Teff is also supported by analysis of a panel of retrogenic mice, which had T cells with TCRs of varying functional avidity for $\mathrm{MOG}_{35-55}$ as a surrogate readout of TCR affinity. This study concluded that $\mathrm{T}$ cell affinity did not determine disease pathogenesis [119]. Furthermore, in relapse/remitting EAE in non-obese diabetic (NOD) mice, the TCR affinity at the secondary progressive remitting stages was equal to or lower to other points in disease [64]. This is not to say that affinity might not alter the kinetics of disease, but rather to emphasize the point that lower affinity $\mathrm{T}$ cells are functional and capable of driving disease.

A second example is in T1D. A panel of eight insulin-reactive InsB $_{9-23}$ specific retrogenic MHC II-restricted TCRs with a broad range of 2D affinity was used to probe the relationship between TCR affinity and disease [87]. Clones with intermediate affinities correlated with the earliest onset of diabetes but the lowest affinity clone induced the highest rate of diabetic incidence. The highest affinity retrogenic clone $\mathrm{P} 2$ and the second lowest $12-4.4 \mathrm{~m} 1$ did not generate spontaneous disease demonstrating that higher affinity Teff are not necessarily the most functional. 


\subsection{T Follicular Helper Cells (Tfh)}

Tfh are a population of T effector cells characterized by the production of IL-21 and the surface expression of PD-1 and CXCR5 driven by the transcription factor Bcl-6 [120-123]. They are critical in providing $B$ cell help to drive humoral immune responses. Based on tetramer staining, Tfh have been suggested to be regulated by the strength of $T$ cell antigen receptor binding [124]. We have shown that TCRs on developing Tfh have a significantly higher 2D affinity than non-Tfh effector CD4+ T cells [125]. Importantly, this differentiation corresponded to initial IL-2 production with the early high producers becoming Tfh.

Potential similarities are also seen with a population of IL-21-producing CD4+ T cells in the CNS after infection with mouse polyoma virus (MuPyV) [126]. IL-21 producers are thought to be essential for CD8+ $\mathrm{T}$ cell differentiation into resident memory $\mathrm{T}$ cells in the brain after infection with MuPyV. IL-21+ CD4+ T cells demonstrated higher 2D affinity than non-IL-21 producers [126], indicating that in this system higher affinity $\mathrm{T}$ cells may be protective against subsequent reactivation of MuPyV infection.

\subsection{Tregs}

For several years it has been thought that Tregs harbored TCRs with higher affinity for pMHC [127-129]. However, 2D-micropipette analysis of MOG reactive Tregs in EAE revealed that the affinity profile of TCRs on Teff and Tregs is in fact very similar in this model [81]. There was also a subtle, but significant, decrease in polyclonal 2D affinity for $\mathrm{MOG}_{38-49}$ reactive Tregs in the CNS as EAE progressed [81], suggesting a mechanism for potential escape from immune regulation as autoimmune disease advances. The idea that Tregs are not driven by high affinity interactions of TCR with pMHC is also supported by data from a mouse model of T1D where low and high affinity Tregs were recruited to the pancreas [130].

\subsection{Memory T Cells}

Memory T cells are critical to recall responses upon reinfection with the same pathogen or in the context of vaccination. One report has demonstrated that memory cells may have a different affinity profile compared to Teff [69]. Using the LCMV model of viral infection in mice, it has been shown that, at the peak of infection, Teff cells to the dominant MHC-II restricted GP $_{66-77}$ epitope are higher affinity [69] whereas cells transitioning to memory $\mathrm{CD} 4+\mathrm{T}$ cells have a lower affinity. A similar observation has also been shown in MuPyV infection where memory CD8+ T cells found in the periphery (spleen) had decreased affinity as compared to the affinity at peak day 8 response [131]. The mechanisms underlying these observations are unknown but may be related to different transcriptional programs initiated by lower affinity TCR signaling programs. Memory T cells can also arise in cases where one has not seen the antigen as defined by the use of tetramers, and analysis of low and high affinity TCRs revealed similar levels of cross-reactivity [132]. The emergence of the novel severe acute respiratory syndrome coronavirus 2 (SARS-CoV-2) in late 2019 show the involvement of CD4+ T cells [133-137] in people who had not been exposed to SARS-CoV-2 [134,136]. Utilization of techniques to measure the range $\mathrm{T}$ cell affinities in such cross-reactive $\mathrm{T}$ cells could be critically informative for predicting patients who present with acute, chronic, and mild disease.

\section{High and Low Affinity CD8+ T Cells}

\subsection{Effector CD8+ T Cells}

Similar to CD4+ T cells, tetramer analysis can miss lower affinity CD8+ T cells and optimized tetramer staining protocols need to be employed for identification of a more complete population of antigen-reactive viral- and tumor-specific CD8+ T cells [62]. However, even with optimized approaches, tetramer staining does not include the levels of antigen-reactive $\mathrm{T}$ cells that are identified by $2 \mathrm{D}$-micropipette. In comparison with $\mathrm{CD} 4+\mathrm{T}$ cells, the idea that high affinity CD8+ $\mathrm{T}$ cell 
interactions are optimal for function during an immune response has more support. For example, data using ovalbumin (OVA) APLs as a surrogate for affinity, suggests that high affinity CD8+ $T$ cells predominantly generate short-lived effector cells (SLEC) [75]. Furthermore, a study of human diabetogenic CD8+ T cells (HLA-A2-ALWGPDPAAA) stimulated with panel of agonist APLs to give a profile of a 3-log range of affinity demonstrated there was a strong positive correlation with affinity and the EC50 of the lytic response [138]. When these cells were stimulated, the higher affinity ligands induced more lysis than the lower affinity ligands. Importantly, all ligands induced lytic functions in this $\mathrm{T}$ cell line demonstrating that higher affinity interactions are not absolutely required for CD8+ $\mathrm{T}$ cell lytic function.

In a key cancer study of three patients who received autologous CD8+ T cells transduced with a with TIL1383I-TCR, it was found that the 2D measurements correlated with outcome. The patient with complete remission demonstrated the highest affinity and the unresponsive patient had a significantly lower affinity [139]. In another study using human tumor-reactive CD8+ T cells, lower affinity altered peptide ligands correlated with reduced calcium release indicating less activation [25]. This supports the idea that lower affinity $\mathrm{T}$ cells respond but at somewhat reduced levels in a cancer setting.

\subsection{Memory CD8+ T Cells}

With respect to memory cells [69], polyclonal CD8+ T cells are similar to CD4+ T cells and exhibit lower affinity during memory responses [65,76]. Again, using again the OVA based APL system with OT-I T cell transgenic cells, both high affinity (N4 pMHC-I) and low affinity (V4 pMHC-I) induced proliferation, although the lower affinity peptide induced cell division to a lesser extent $[37,140]$. However upon stimulation, V4 pMHC-I induced a greater differentiation of OT-I cells with a memory phenotype [76] than those cells interacting with high affinity ligands [37,140]. Given these results, one could propose that, at peak disease high affinity $\mathrm{T}$ cells in response to dominant epitopes would generate mostly SLEC and lower affinity T cells would favor memory precursor effector cells (MPEC). Nevertheless, not all types of memory CD8+ T cells are favored by lower affinity. Studies from two different infections in the central nervous system show that tissue resident memory CD8+ T cells (Trem) are of higher affinity. In vivo tracking of three CD8+ T cell clones reactive to epitopes of the ROP7 antigen of Toxoplasma gondii, found that it was the two highest affinity clones that trafficked to the brain (R7-I and R7-III) during acute infection and these clones were maintained as CD103+ Trm [141]. Similarly the CD8+ resident memory T cells in the brains of MuPyV-infected mice have also been shown to harbor higher affinity TCRs as compared to the memory cells found in the spleen [131]. Whilst more work needs to be carried out to determine if there are generalized patterns whereby memory CD8+ T cells have a predilection for a particular affinity profile, data thus far suggests that affinity may have different effects on memory $\mathrm{T}$ cell fate.

\section{Conclusions}

A comprehensive understanding of the varied roles of $\mathrm{T}$ cells during adaptive immune responses can be achieved through a focus on $2 \mathrm{D}$ binding kinetics of antigen recognition as it relates to effector function. The contribution of lower affinity $\mathrm{T}$ cells has been overlooked due to sensitivity limitations of commonly used assays often requiring multimerized pMHCs for detection. Without inclusion of all antigen-reactive T cells, which can only be identified with sensitive tools such as the 2D micropipette, interpretation of antigen specificity and $\mathrm{T}$ cell frequency and function can be misleading. Here, we have highlighted the importance of lower affinity $\mathrm{T}$ cells that have previously escaped detection in a variety of model systems. T cells with lower affinity TCRs expand and are functional with the evidence thus far suggesting there can be differences in functional phenotype. Employing sensitive measures of $\mathrm{T}$ cell affinity in future studies will allow for more in-depth analysis of immune responses which in turn will facilitate the development of therapeutic interventions based on information that encompasses the entire affinity range found in the $\mathrm{T}$ cell population. 
Funding: This article was funded by R01 grants NS071518 and AI147641 to B.D.E.

Conflicts of Interest: The authors declare no conflict of interest.

\section{References}

1. Corse, E.; Gottschalk, R.A.; Allison, J.P. Strength of TCR-Peptide/MHC interactions and in vivo T cell responses. J. Immunol. 2011, 186, 5039-5045. [CrossRef] [PubMed]

2. Van der Merwe, P.A.; Dushek, O. Mechanisms for T cell receptor triggering. Nature 2010, 11, 47-55. [CrossRef] [PubMed]

3. Krogsgaard, M.; Prado, N.; Adams, E.J.; He, X.L.; Chow, D.C.; Wilson, D.B.; Garcia, K.C.; Davis, M.M. Evidence that structural rearrangements and/or flexibility during TCR binding can contribute to T cell activation. Mol. Cell 2003, 12, 1367-1378. [CrossRef]

4. Matsui, K.; Boniface, J.J.; Steffner, P.; Reay, P.A.; Davis, M.M. Kinetics of T-cell receptor binding to peptide/I-Ek complexes: Correlation of the dissociation rate with T-cell responsiveness. Proc. Natl. Acad. Sci. USA 1994, 91, 12862-12866. [CrossRef]

5. Corr, M.; Slanetz, A.E.; Boyd, L.F.; Jelonek, M.T.; Khilko, S.; Al-ramadi, B.K. T cell receptor-MHC class I peptide interactions: Affinity, kinetics, and specificity. Science 1994, 265, 51-54. [CrossRef]

6. Davis, M.M.; Krogsgaard, M.; Huppa, J.B.; Sumen, C.; Purbhoo, M.A.; Irvine, D.J.; Wu, L.C.; Ehrlich, L. Dynamics of cell surface molecules during T cell recognition. Annu. Rev. Biochem. 2003, 72, 717-742. [CrossRef]

7. Irvine, D.; Purbhoo, M.; Krogsgaard, M.; Davis, M. Direct observation of ligand recognition by T cells. Nature 2002, 419, 845-849. [CrossRef] [PubMed]

8. Purbhoo, M.A.; Irvine, D.J.; Huppa, J.B.; Davis, M.M. T cell killing does not require the formation of a stable mature immunological synapse. Nat. Immunol. 2004, 5, 524-530. [CrossRef]

9. Harding, C.V.; Unanue, E.R. Quantitation of antigen-presenting cell MHC class II/peptide complexes necessary for T-cell stimulation. Nature 1990, 346, 574-576. [CrossRef]

10. Germain, R.N.; Stefanová, I. The dynamics of T cell receptor signaling: Complex orchestration and the key roles of tempo and cooperation. Annu. Rev. Immunol. 1999, 17, 467-522. [CrossRef]

11. Kersh, G.J.; Allen, P.M. Essential flexibility in the T cell recognition of antigen. Nature 1996, 380, 495-498. [CrossRef] [PubMed]

12. Yu, W.; Jiang, N.; Ebert, P.J.R.; Kidd, B.A.; Müller, S.; Lund, P.J.; Juang, J.; Adachi, K.; Tse, T.; Birnbaum, M.E.; et al. Clonal deletion prunes but does not eliminate self-specific $\alpha \beta C D 8^{+} \mathrm{T}$ lymphocytes. Immunity 2015, 42, 929-941. [CrossRef]

13. Stritesky, G.L.; Jameson, S.C.; Hogquist, K.A. Selection of self-reactive $\mathrm{T}$ cells in the thymus. Annu. Rev. Immunol. 2012, 30, 95-114. [CrossRef] [PubMed]

14. Bielekova, B.; Sung, M.-H.; Kadom, N.; Simon, R.; McFarland, H.; Martin, R. Expansion and functional relevance of high-avidity myelin-specific CD4+ T cells in multiple sclerosis. J. Immunol. 2004, 172, 3893-3904. [CrossRef] [PubMed]

15. Garcia, K.C.; Radu, C.G.; Ho, J.; Ober, R.J.; Ward, E.S. Kinetics and thermodynamics of T cell receptor-autoantigen interactions in murine experimental autoimmune encephalomyelitis. Proc. Natl. Acad. Sci. USA 2001, 98, 6818-6823. [CrossRef] [PubMed]

16. Stone, J.D.; Chervin, A.S.; Kranz, D.M. T-cell receptor binding affinities and kinetics: Impact on T-cell activity and specificity. Immunology 2009, 126, 165-176. [CrossRef]

17. Kersh, G.J.; Kersh, E.N.; Fremont, D.H.; Allen, P.M. High- and low-potency ligands with similar affinities for the TCR: The importance of kinetic in TCR signaling. Immunity 1998, 9, 817-826. [CrossRef]

18. Alam, S.M.; Davies, G.M.; Lin, C.M.; Zal, T.; Nasholds, W.; Jameson, S.C.; Hogquist, K.A.; Gascoigne, N.R.J.; Travers, P.J.; Jolla, L.; et al. Qualitative and quantitative differences in $\mathrm{T}$ cell receptor binding of agonist and antagonist ligands. Immunity 1999, 10, 227-237. [CrossRef]

19. Rosette, C.; Werlen, G.; Daniels, M.A.; Holman, P.O.; Alam, S.M.; Travers, P.J.; Gascoigne, N.R.J.; Palmer, E.; Jameson, S.C. The Impact of duration versus extent of TCR occupancy on T cell activation: A revision of the kinetic proofreading model. Immunity 2001, 15, 59-70. [CrossRef] 
20. Hebeisen, M.; Schmidt, J.; Guillaume, P.; Baumgaertner, P.; Speiser, D.E.; Luescher, I.; Rufer, N. Identification of rare high-avidity, tumor-reactive CD8 p T cells by monomeric TCR-ligand off-rates measurements on living cells. Cancer Res. 2015, 75, 1983-1991. [CrossRef]

21. Schmid, D.A.; Irving, M.B.; Posevitz, V.; Hebeisen, M.; Posevitz-Fejfar, A.; Sarria, J.C.F.; Gomez-Eerland, R.; Thome, M.; Schumacher, T.N.M.; Romero, P.; et al. Evidence for a TCR affinity threshold delimiting maximal CD8 T cell function. J. Immunol. 2010, 184, 4936-4946. [CrossRef] [PubMed]

22. Adams, J.J.; Narayanan, S.; Liu, B.; Birnbaum, M.E.; Kruse, A.C.; Bowerman, N.A.; Chen, W.; Levin, A.M.; Connolly, J.M.; Zhu, C.; et al. T cell receptor signaling is limited by docking geometry to peptide-major histocompatibility complex. Immunity 2011, 35, 681-693. [CrossRef] [PubMed]

23. Zhong, S.; Malecek, K.; Johnson, L.A.; Yu, Z.; Vega-Saenz de Miera, E.; Darvishian, F.; McGary, K.; Huang, K.; Boyer, J.; Corse, E.; et al. T-cell receptor affinity and avidity defines antitumor response and autoimmunity in T-cell immunotherapy. Proc. Natl. Acad. Sci. USA 2013, 110, 6973-6978. [CrossRef]

24. Alam, S.M.; Travers, P.J.; Wung, J.L.; Nasholds, W.; Redpath, S.; Jameson, S.C.; Gascoigne, N.R.J. T-cell-receptor affinity and thymocyte positive selection. Nature 1996, 381, 616-620. [CrossRef] [PubMed]

25. Chen, J.; Morgan, A.J.; Stewart-jones, G.; Shepherd, D.; Bossi, G.; Wooldridge, L.; Hutchinson, L.; Sewell, A.K.; Griffiths, G.M.; Van Der Merwe, A.; et al. Ca 2+ release from the endoplasmic reticulum of NY-ESO-1-specific $\mathrm{T}$ cells is modulated by the affinity of TCR and by the use of the CD8 coreceptor. J. Immunol. 2010, 184, 1829-1839. [CrossRef]

26. Gras, S.; Chadderton, J.; Del Campo, C.M.; Quinn, K.M.; Rossjohn, J.; La Gruta, N.L.; Gras, S.; Chadderton, J.; Del Campo, C.M.; Farenc, C.; et al. Reversed T cell receptor docking on a major histocompatibility class I complex limits involvement in the immune response reversed $\mathrm{T}$ cell receptor docking on a major histocompatibility class I complex limits involvement in the immune response. Immunity 2016, 45, 749-760. [CrossRef]

27. Holmberg, K.; Mariathasan, S.; Ohteki, T. TCR binding kinetics measured with MHC class I tetramers reveal a positive selecting peptide with relatively high affinity for TCR. J. Immunol. 2003, 171, 2427-2434. [CrossRef]

28. Van der Merwe, P.A. The TCR triggering puzzle. Immunity 2001, 14, 665-668. [CrossRef]

29. Lyons, D.S.; Lieberman, S.A.; Hampl, J.; Boniface, J.J.; Chien, Y.H.; Berg, L.J.; Davis, M.M. A TCR binds to antagonist ligands with lower affinities and faster dissociation rates than to agonists. Immunity 1996, 5, 53-61. [CrossRef]

30. Al-Ramadi, B.K.; Jelonek, M.T.; Boyd, L.F.; Margulies, D.H.; Bothwell, A.L. Lack of strict correlation of functional sensitization with the apparent affinity of MHC/peptide complexes for the TCR. J. Immunol. 1995, 155, 662-673.

31. Allison, K.A.; Sajti, E.; Collier, J.G.; Gosselin, D.; Troutman, T.D.; Stone, E.L.; Hedrick, S.M.; Glass, C.K. Affinity and dose of TCR engagement yield proportional enhancer and gene activity in CD4+ T cells. eLife 2016, 5, 1-28. [CrossRef] [PubMed]

32. Gottschalk, R.A.; Hathorn, M.M.; Beuneu, H.; Corse, E.; Dustin, M.L. Distinct in fl uences of peptide-MHC quality and quantity on in vivo T-cell responses. Proc. Natl. Acad. Sci. USA 2012, 109, 881-886. [CrossRef] [PubMed]

33. Govern, C.C.; Paczosa, M.K.; Chakraborty, A.K.; Huseby, E.S. Fast on-rates allow short dwell time ligands to activate T cells. Proc. Natl. Acad. Sci. USA 2010, 107, 8724-8729. [CrossRef] [PubMed]

34. Tian, S.; Maile, R.; Collins, E.J.; Frelinger, J.A. CD8+ T cell activation is governed by TCR-peptide/MHC affinity, not dissociation rate. J. Immunol. 2007, 179, 2952-2960. [CrossRef] [PubMed]

35. Huang, J.; Zarnitsyna, V.I.; Liu, B.; Edwards, L.J.; Jiang, N.; Evavold, B.D.; Zhu, C. The kinetics of two-dimensional TCR and pMHC interactions determine T-cell responsiveness. Nature 2010, 464, 932-936. [CrossRef]

36. Kalergis, A.H.; Boucheron, N.; Doucey, M.A.; Palmieri, E.; Goyarts, E.C.; Vegh, Z.; Luescher, I.F.; Nathenson, S.G. Efficient $\mathrm{T}$ cell activation requires an optimal dwell-time of interaction between the TCR and the pMHC complex. Nat. Immunol. 2001, 2, 229-234. [CrossRef] [PubMed]

37. Zehn, D.; Lee, S.Y.; Bevan, M.J. Complete but curtailed T-cell response to very low-affinity antigen. Nature 2009, 458, 211-214. [CrossRef] [PubMed]

38. Coombs, D.; Mora, J.E.; Palmieri, E.; Goldstein, B.; Gonza, P.A.; Nathenson, S.G.; Kalergis, A.M. T cell receptor binding kinetics required for $\mathrm{T}$ cell activation depend on the density of cognate ligand on the antigen-presenting cell. Proc. Natl. Acad. Sci. USA 2005, 102, 4824-4829. [CrossRef] 
39. Davis, M.M.; Boniface, J.J.; Reich, Z.; Lyons, D.; Hampl, J.; Arden, B.; Chien, Y. Ligand recognition by A $\beta$ T cell receptors. Annu. Rev. Immunol. 1998, 16, 523-544. [CrossRef] [PubMed]

40. Tolentino, T.P.; Wu, J.; Zarnitsyna, V.I.; Fang, Y.; Dustin, M.L.; Zhu, C. Measuring diffusion and binding kinetics by contact area FRAP. Biophys. J. 2008, 95, 920-930. [CrossRef]

41. Wu, J.; Fang, Y.; Zarnitsyna, V.I.; Tolentino, T.P.; Dustin, M.L.; Zhu, C. A coupled diffusion-kinetics model for analysis of contact-area FRAP experiment. Biophys. J. 2008, 95, 910-919. [CrossRef] [PubMed]

42. Huppa, J.B.; Axmann, M.; Mörtelmaier, M.A.; Lillemeier, B.F.; Newell, E.W.; Brameshuber, M.; Klein, L.O.; Schütz, G.J.; Davis, M.M. TCR-peptide-MHC interactions in situ show accelerated kinetics and increased affinity. Nature 2010, 463, 963-967. [CrossRef]

43. Edwards, L.J.; Zarnitsyna, V.I.; Hood, J.D.; Evavold, B.D.; Zhu, C. Insights into T cell recognition of antigen: Significance of two-dimensional kinetic parameters. Front. Immunol. 2012, 3, 1-9. [CrossRef] [PubMed]

44. Blanchfield, J.; Shorter, S.K.; Evavold, B.D. Monitoring the dynamics of T cell clonal diversity using recombinant peptide:MHC technology. Front. Immunol. 2013, 4, 1-9. [CrossRef] [PubMed]

45. Zhang, S.-Q.; Parker, P.; Ma, K.-Y.; He, C.; Shi, Q.; Cui, Z.; Williams, C.M.; Wendel, B.S.; Meriwether, A.I.; Salazar, M.A.; et al. Direct measurement of $\mathrm{T}$ cell receptor affinity and sequence from naive antiviral $\mathrm{T}$ cells. Sci. Transl. Med. 2016, 8, 341ra77. [CrossRef]

46. Seo, Y.J.; Jothikumar, P.; Suthar, M.S.; Zhu, C.; Grakoui, A. Local cellular and cytokine cues in the spleen regulate in situ T cell receptor affinity, function, and fate of CD8+ T cells. Immunity 2016, 45, 988-998. [CrossRef]

47. Chesla, S.E.; Selvaraj, P.; Zhu, C. Measuring two-dimensional receptor-ligand binding kinetics by micropipette. Biophys. J. 1998, 75, 1553-1572. [CrossRef]

48. Harrison, D.L.; Fang, Y.; Huang, J. T-cell mechanobiology: Force sensation, potentiation, and translation. Front. Phys. 2019, 7, 1-18. [CrossRef]

49. Huang, J.; Zeng, X.; Sigal, N.; Lund, P.J.; Su, L.F.; Huang, H.; Chien, Y.; Davis, M.M. Detection, phenotyping, and quantification of antigen-specific T cells using a peptide-MHC dodecamer. Proc. Natl. Acad. Sci. USA 2016, 113, E1890-E1897. [CrossRef]

50. Batard, P.; Peterson, D.A.; Devêvre, E.; Guillaume, P.; Cerottini, J.; Rimoldi, D.; Speiser, D.E.; Winther, L.; Romero, P. Dextramers: New generation of fluorescent MHC class I/peptide multimers for visualization of antigen-specific CD8 + T cells. J. Immunol. Methods 2006, 310, 136-148. [CrossRef]

51. Dolton, G.; Lissina, A.; Ladell, K.; Tungatt, K.; Jones, E.; Kronenberg-Versteeg, D.; Akpovwa, H.; Pentier, J.; Holland, C.; Godkin, A.; et al. Comparison of peptide-major histocompatibility complex tetramers and dextramers for the identification of antigen-specific T cells. Clin. Exp. Immunol. 2014, 177, 47-63. [CrossRef]

52. Altman, A.J.D.; Moss, P.A.H.; Goulder, P.J.R.; Barouch, D.H.; Mcheyzer-williams, M.G.; Bell, J.I. Phenotypic analysis of antigen-specific T lymphocytes. Science 1996, 20-22. [CrossRef]

53. Kim, C.; Wilson, T.; Fischer, K.F.; Williams, M.A. Sustained interactions between T cell receptors and antigens promote the differentiation of CD4+ memory T cells. Immunity 2013, 39, 508-520. [CrossRef] [PubMed]

54. Crawford, F.; Kozono, H.; White, J.; Marrack, P.; Kappler, J. Detection of antigen-specific T cells with multivalent soluble class II MHC covalent peptide complexes. Immunity 1998, 8, 675-682. [CrossRef]

55. Wooldridge, L.; Wooldridge, L.; Cole, D.K.; Van Den Berg, H.A.; Price, D.A.; Sewell, A.K. Tricks with tetramers: How to get the most from multimeric peptide-MHC. Immunology 2009, 126, 147-164. [CrossRef] [PubMed]

56. Wooldridge, L.; Van Den Berg, H.A.; Glick, M.; Gostick, E.; Laugel, B.; Hutchinson, S.L.; Milicic, A.; Brenchley, J.M.; Douek, D.C.; Price, D.A.; et al. Interaction between the CD8 coreceptor and major histocompatibility complex class I stabilizes T cell receptor-antigen complexes at the cell surface. J. Biol. Chem. 2005, 280, 27491-27501. [CrossRef]

57. Holler, P.D.; Kranz, D.M. Quantitative analysis of the contribution of TCR/pepMHC affinity and CD8 to T cell activation. Immunity 2003, 18, 255-264. [CrossRef]

58. Boniface, J.J.; Rabinowitz, J.D.; Wu, C.; Hampl, J.; Reich, Z.; Altman, J.D.; Kantor, R.M.; Beeson, C.; Mcconnell, H.M.; Davis, M.M. Initiation of signal transduction through the T cell receptor requires the multivalent engagement of peptide/MHC ligands. Immunity 1998, 9, 459-466. [CrossRef]

59. Xiong, Y.; Kern, P.; Chang, H.; Reinherz, E.L. T Cell receptor binding to a pMHCII ligand Is kinetically distinct from and independent of CD4 *. J. Biol. Chem. 2001, 276, 5659-5667. [CrossRef] 
60. Masopust, D.; Murali-krishna, K.; Ahmed, R. Quantitating the magnitude of the lymphocytic choriomeningitis virus-specific CD8 T-cell response: It is even bigger than we thought. J. Virol. 2007, 81, 2002-2011. [CrossRef]

61. Stone, J.D.; Cochran, J.R.; Stern, L.J. T-cell activation by soluble MHC oligomers can be described by a two-parameter binding model. Biophys. J. 2001, 81, 2547-2557. [CrossRef]

62. Rius, C.; Attaf, M.; Tungatt, K.; Bianchi, V.; Legut, M.; Bovay, A.; Donia, M.; thor Straten, P.; Peakman, M.; Svane, I.M.; et al. Peptide-MHC class I tetramers can fail to detect relevant functional T cell clonotypes and underestimate antigen-reactive T cell populations. J. Immunol. 2018, 200, 2263-2279. [CrossRef]

63. Sabatino, J.J.; Huang, J.; Zhu, C.; Evavold, B.D. High prevalence of low affinity peptide-MHC II tetramer-negative effectors during polyclonal $\mathrm{CD}^{+} \mathrm{T}$ cell responses. J. Exp. Med. 2011, 208, 81-90. [CrossRef] [PubMed]

64. Kersh, A.E.; Edwards, L.J.; Evavold, B.D. Progression of relapsing-remitting demyelinating disease does not require increased TCR affinity or epitope spread. J. Immunol. 2014, 193, 4429-4438. [CrossRef]

65. Krummey, S.M.; Morris, A.B.; Jacobs, J.R.; Evavold, B.D.; Kissick, H.T.; Ford, M.L. CD45RB status of CD8+ $\mathrm{T}$ cell memory defines $\mathrm{T}$ cell receptor affinity and persistence report CD45RB status of CD8+ T cell memory defines T cell receptor. Cell Rep. 2020, 30, 1282-1291. [CrossRef] [PubMed]

66. Minguet, S.; Ortı, A.R.; Schamel, W.W.A.; Risuen, R.M. A conformation- and avidity-based proofreading mechanism for the TCR-CD3 complex. Trends Immunol. 2006, 27, 176-182. [CrossRef]

67. Dolton, G.; Tungatt, K.; Lloyd, A.; Theaker, S.M.; Trimby, A.; Christopher, J.; Donia, M.; Andrew, J.; Cole, D.K.; Thor, P.; et al. More tricks with tetramers: A practical guide to staining T cells with peptide-MHC multimers. Immunology 2015, 146, 11-22. [CrossRef]

68. Evans, E.; Leung, A.; Heinrich, V.; Zhu, C. Mechanical switching and coupling between two dissociation pathways in a P-selectin adhesion bond. Proc. Natl. Acad. Sci. USA 2004, 101, 11281-11286. [CrossRef] [PubMed]

69. Andargachew, R.; Martinez, R.J.; Kolawole, E.M.; Evavold, B.D. CD4 T cell affinity diversity is equally maintained during acute and chronic infection. J. Immunol. 2018, 201, 19-30. [CrossRef] [PubMed]

70. Blanchfield, L.; Sabatino, J.J.; Lawrence, L.; Evavold, B.D. NFM cross-reactivity to MOG does not expand a critical threshold level of high-affinity T cells necessary for onset of demyelinating disease. J. Immunol. 2017, 199, 2680-2691. [CrossRef]

71. Liu, B.; Hood, J.D.; Kolawole, E.M.; Woodruff, D.M.; Vignali, D.A.; Bettini, M.; Evavold, B.D. A hybrid insulin epitope maintains high 2D affinity for diabetogenic T cells in the periphery. Diabetes 2020, 69, 381-391. [CrossRef] [PubMed]

72. Zhu, C.; Jiang, N.; Zarnitsyna, V.I.; Evavold, B.D. Insights from in situ analysis of TCR-pMHC recognition: Response of an interaction network. Immunol. Rev. 2013, 251, 49-64. [CrossRef]

73. Savage, P.A.; Boniface, J.J.; Davis, M.M. A kinetic basis for T cell receptor repertoire selection during an immune response. Immunity 1999, 10, 485-492. [CrossRef]

74. Koehli, S.; Naeher, D.; Galati-Fournier, V.; Zehn, D.; Palmer, E. Optimal T-cell receptor affinity for inducing autoimmunity. Proc. Natl. Acad. Sci. USA 2014, 111, 17248-17253. [CrossRef]

75. King, C.G.; Koehli, S.; Hausmann, B.; Schmaler, M.; Zehn, D.; Palmer, E. T cell affinity regulates asymmetric division, effector cell differentiation, and tissue pathology. Immunity 2012, 37, 709-720. [CrossRef]

76. Krummey, S.M.; Martinez, R.J.; Andargachew, R.; Liu, D.; Wagener, M.; Kohlmeier, J.E.; Evavold, B.D.; Larsen, C.P.; Ford, M.L. Low-affinity memory CD8+ T cells mediate robust heterologous immunity. J. Immunol. 2016, 196, 2838-2846. [CrossRef] [PubMed]

77. Laugel, B.; Van Den Berg, H.A.; Gostick, E.; Cole, D.K.; Wooldridge, L.; Boulter, J.; Milicic, A.; Price, D.A.; Sewell, A.K. Different T cell receptor affinity thresholds and CD8 coreceptor dependence govern cytotoxic T lymphocyte activation and tetramer binding properties. J. Biol. Chem. 2007, 282, 23799-23810. [CrossRef] [PubMed]

78. Tungatt, K.; Bianchi, V.; Crowther, M.D.; Powell, W.E.; Schauenburg, A.J.; Trimby, A.; Donia, M.; Miles, J.J.; Holland, C.J.; Cole, D.K.; et al. Antibody stabilization of peptide-MHC multimers reveals functional T cells bearing extremely low-affinity TCRs. J. Immunol. 2015, 194, 463-474. [CrossRef]

79. Gebe, J.A.; Falk, B.A.; Rock, K.A.; Kochik, S.A.; Heninger, A.K.; Reijonen, H.; Kwok, W.W.; Nepom, G.T. Low-avidity recognition by CD4+ T cells directed to self-antigens. Eur. J. Immunol. 2003, 33, 1409-1417. [CrossRef] [PubMed] 
80. Falta, M.T.; Fontenot, A.P.; Rosloniec, E.F.; Crawford, F.; Roark, C.L.; Bill, J.; Marrack, P.; Kappler, J.; Kotzin, B.L. Class II major histocompatibility complex-Peptide tetramer staining in relation to functional avidity and $\mathrm{T}$ cell receptor diversity in the mouse CD4+ T cell response to a rheumatoid arthritis-Associated antigen. Arthritis Rheum. 2005, 52, 1885-1896. [CrossRef]

81. Hood, J.D.; Zarnitsyna, V.I.; Zhu, C.; Evavold, B.D. Regulatory and T effector cells have overlapping low to high ranges in TCR affinities for self during demyelinating disease. J. Immunol. 2015, 195, 4162-4170. [CrossRef] [PubMed]

82. Bettini, M.; Scavuzzo, M.A.; Liu, B.; Kolawole, E.; Guo, L.; Evavold, B.D.; Borowiak, M.; Bettini, M.L. A critical insulin TCR contact residue selects high-affinity and pathogenic insulin-specific T cells. Diabetes 2020, 69, 392-400. [CrossRef] [PubMed]

83. Nelson, R.W.; Beisang, D.; Tubo, N.J.; Dileepan, T.; Wiesner, D.L.; Nielsen, K.; Wüthrich, M.; Klein, B.S.; Kotov, D.I.; Spanier, J.A.; et al. T cell receptor cross-reactivity between similar foreign and self peptides influences naive cell population size and autoimmunity. Immunity 2015, 42, 95-107. [CrossRef]

84. Martinez, R.J.; Andargachew, R.; Martinez, H.A.; Evavold, B.D. Low-affinity CD4 T cells are major responders in the primary immune response. Nat. Commun. 2016, 7, 1-10. [CrossRef]

85. Rosenthal, K.M.; Edwards, L.J.; Sabatino, J.J.; Hood, J.D.; Wasserman, H.A.; Zhu, C.; Evavold, B.D. Low 2-dimensional CD4 $\mathrm{T}$ cell receptor affinity for myelin sets in motion delayed response kinetics. PLoS ONE 2012, 7, e32562. [CrossRef] [PubMed]

86. Schubert, D.A.; Gordo, S.; Sabatino, J.J.; Vardhana, S.; Gagnon, E.; Sethi, D.K.; Seth, N.P.; Choudhuri, K.; Reijonen, H.; Nepom, G.T.; et al. Self-reactive human CD4 T cell clones form unusual immunological synapses. J. Exp. Med. 2012, 209, 335-352. [CrossRef] [PubMed]

87. Bettini, M.; Blanchfield, L.; Castellaw, A.; Zhang, Q.; Nakayama, M.; Smeltzer, M.P.; Zhang, H.; Hogquist, K.A.; Evavold, B.D.; Vignali, D.A.A. TCR affinity and tolerance mechanisms converge to shape T cell diabetogenic potential. J. Immunol. 2014, 193, 571-579. [CrossRef] [PubMed]

88. Liu, B.; Chen, W.; Evavold, B.D.; Zhu, C. Accumulation of dynamic catch bonds between TCR and agonist peptide-MHC triggers T cell signaling. Cell 2014, 157, 357-368. [CrossRef]

89. Pryshchep, S.; Zarnitsyna, V.I.; Hong, J.; Evavold, B.D.; Zhu, C. Accumulation of serial forces on TCR and CD8 frequently applied by agonist antigenic peptides embedded in MHC molecules triggers calcium in T cells. J. Immunol. 2014, 193, 68-76. [CrossRef]

90. Liu, Y.; Blanchfield, L.; Ma, V.P.-Y.; Andargachew, R.; Galior, K.; Liu, Z.; Evavold, B.; Salaita, K. DNA-based nanoparticle tension sensors reveal that T-cell receptors transmit defined $\mathrm{pN}$ forces to their antigens for enhanced fidelity. Proc. Natl. Acad. Sci. USA 2016, 113, 5610-5615. [CrossRef]

91. Artyomov, M.N.; Lis, M.; Devadas, S.; Davis, M.M.; Chakraborty, A.K. CD4 and CD8 binding to MHC molecules primarily acts to enhance Lck delivery. Proc. Natl. Acad. Sci. USA 2010, 107, 16916-16921. [CrossRef] [PubMed]

92. Huang, J.; Edwards, L.J.; Evavold, B.D.; Zhu, C. Kinetics of MHC-CD8 interaction at the T cell membrane. J. Immunol. 2007, 179, 7653-7662. [CrossRef]

93. Kolawole, E.M.; Andargachew, R.; Liu, B.; Jacobs, J.R.; Evavold, B.D. 2D kinetic analysis of TCR and CD8 coreceptor for LCMV GP33 epitopes. Front. Immunol. 2018, 9, 1-12. [CrossRef]

94. Jiang, N.; Huang, J.; Edwards, L.J.; Liu, B.; Zhang, Y.; Beal, C.D.; Evavold, B.D.; Zhu, C. Two-stage cooperative $\mathrm{T}$ cell receptor-peptide major histocompatibility complex-CD8 trimolecular interactions amplify antigen discrimination. Immunity 2011, 34, 13-23. [CrossRef]

95. Aleksic, M.; Dushek, O.; Zhang, H.; Shenderov, E.; Chen, J.; Cerundolo, V.; Coombs, D.; Van Der Merwe, P.A. Dependence of $\mathrm{T}$ cell antigen recognition on T cell receptor-peptide MHC confinement time. Immunity 2010, 32, 163-174. [CrossRef] [PubMed]

96. Klammt, C.; Novotná, L.; Li, D.T.; Wolf, M.; Blount, A.; Zhang, K.; Fitchett, J.R.; Lillemeier, B.F. T cell receptor dwell times control the kinase activity of Zap70. Nat. Immunol. 2015, 16, 961-968. [CrossRef] [PubMed]

97. Stadinski, B.D.; Blevins, S.J.; Spidale, N.A.; Duke, B.R.; Huseby, P.G.; Stern, L.J.; Huseby, E.S. A temporal thymic selection switch and ligand binding kinetics constrain neonatal Foxp3+ Treg cell development. Nat. Immunol. 2019, 20, 1046-1058. [CrossRef]

98. Huse, M. Mechanical forces in the immune system. Nat. Rev. Immunol. 2017, 17, 679-690. [CrossRef]

99. Depoil, D.; Dustin, M.L. Force and affinity in ligand discrimination by the TCR. Trends Immunol. 2014, 35, 597-603. [CrossRef] 
100. Cost, A.L.; Ringer, P.; Chrostek-Grashoff, A.; Grashoff, C. How to measure molecular forces in cells: A guide to evaluating genetically-encoded FRET-based tension sensors. Cell. Mol. Bioeng. 2015, 8, 96-105. [CrossRef]

101. Hu, K.H.; Butte, M.J. T cell activation requires force generation. J. Cell Biol. 2016, 213, 535-542. [CrossRef]

102. Hosseini, B.H.; Louban, I.; Djandji, D.; Wabnitz, G.H.; Janosch, D.; Bulbuc, N.; Samstag, Y.; GUnzer, M.; Spatz, J.P.; Hammerling, G.J. Immune synapse formation determines interaction forces between T cells and antigen-presenting cells measured by atomic force microscopy. Proc. Natl. Acad. Sci. USA 2009, 106, 17852-17857. [CrossRef]

103. Puech, P.H.; Nevoltris, D.; Robert, P.; Limozin, L.; Boyer, C.; Bongrand, P. Force measurements of TCR/pMHC recognition at $\mathrm{T}$ cell surface. PLoS ONE 2011, 6, 1-9. [CrossRef] [PubMed]

104. Das, D.K.; Feng, Y.; Mallis, R.J.; Li, X.; Keskin, D.B.; Hussey, R.E.; Brady, S.K.; Wang, J.-H.; Wagner, G.; Reinherz, E.L.; et al. Force-dependent transition in the T-cell receptor $\beta$-subunit allosterically regulates peptide discrimination and pMHC bond lifetime. Proc. Natl. Acad. Sci. USA 2015, 112, 1517-1522. [CrossRef]

105. Hong, J.; Persaud, S.P.; Horvath, S.; Allen, P.M.; Evavold, B.D.; Zhu, C. Force-regulated in situ TCR-peptide-bound MHC class II kinetics determine functions of CD4 ${ }^{+} \mathrm{T}$ cells. J. Immunol. 2015, 195, 3557-3564. [CrossRef] [PubMed]

106. Feng, Y.; Brazin, K.N.; Kobayashi, E.; Mallis, R.J.; Reinherz, E.L.; Lang, M.J. Mechanosensing drives acuity of $\alpha \beta$ T-cell recognition. Proc. Natl. Acad. Sci. USA 2017, 114, E8204-E8213. [CrossRef]

107. Hong, J.; Ge, C.; Jothikumar, P.; Yuan, Z.; Liu, B.; Bai, K.; Li, K.; Rittase, W.; Shinzawa, M.; Zhang, Y.; et al. A TCR mechanotransduction signaling loop induces negative selection in the thymus. Nat. Immunol. 2018, 19, 1379-1392. [CrossRef] [PubMed]

108. Liu, B.; Chen, W.; Natarajan, K.; Li, Z.; Margulies, D.H.; Zhu, C. The cellular environment regulates in situ kinetics of T-cell receptor interaction with peptide major histocompatibility complex. Eur. J. Immunol. 2015, 45, 2099-2110. [CrossRef]

109. Wu, P.; Zhang, T.; Liu, B.; Zhu, C.; Chen, W. Mechano-regulation of peptide-MHC class I conformations determines TCR antigen article mechano-regulation of peptide-MHC class I conformations determines. Mol. Cell 2019, 73, 1015-1027. [CrossRef]

110. Sibener, L.V.; Fernandes, R.A.; Kolawole, E.M.; Carbone, C.B.; Liu, F.; McAffee, D.; Birnbaum, M.E.; Yang, X.; $\mathrm{Su}, \mathrm{L} . \mathrm{F}$; $\mathrm{Yu}, \mathrm{W}$; et al. Isolation of a structural mechanism for uncoupling $\mathrm{T}$ cell receptor signaling from peptide-MHC binding. Cell 2018, 174, 672-687.e27. [CrossRef]

111. Iezzi, G.; Karjalainen, K.; Lanzavecchia, A. The duration of antigenic stimulation determines the fate of naive and effector T cells. Immunity 1998, 8, 89-95. [CrossRef]

112. Tuosto, L.; Acuto, O. CD28 affects the earliest signaling events generated by TCR engagement. Eur. J. Immunol. 1998, 28, 2131-2142. [CrossRef]

113. Garcia, K.C.; Scott, C.A.; Brunmark, A.; Carbone, F.R.; Peterson, P.A.; Wilson, I.A.; Teyton, L. CD8 enhances formation of stable T-cell receptor/MHC class I molecule complexes. Nature 1996, 384, 577-581. [CrossRef] [PubMed]

114. Carbone, C.B.; Kern, N.; Fernandes, R.A.; Hui, E.; Su, X.; Garcia, K.C.; Vale, R.D. In vitro reconstitution of $\mathrm{T}$ cell receptor-mediated segregation of the CD45 phosphatase. Proc. Natl. Acad. Sci. USA 2017, 114, E9338-E9345. [CrossRef] [PubMed]

115. Daniels, M.A.; Teixeiro, E. TCR signaling in T cell memory. Front. Immunol. 2015, 6, 1-10. [CrossRef]

116. Kim, S.T.; Takeuchi, K.; Sun, Z.Y.J.; Touma, M.; Castro, C.E.; Fahmy, A.; Lang, M.J.; Wagner, G.; Reinherz, E.L. The $\alpha \beta$ T cell receptor is an anisotropic mechanosensor. J. Biol. Chem. 2009, 284, 31028-31037. [CrossRef]

117. Gourley, T.S.; Wherry, E.J.; Masopust, D.; Ahmed, R. Generation and maintenance of immunological memory. Semin. Immunol. 2004, 16, 323-333. [CrossRef]

118. Bettelli, E.; Pagany, M.; Weiner, H.L.; Linington, C.; Sobel, R.A.; Kuchroo, V.K. Myelin oligodendrocyte glycoprotein-specific $\mathrm{T}$ cell receptor transgenic mice develop spontaneous autoimmune optic neuritis. J. Exp. Med. 2003, 197, 1073-1081. [CrossRef]

119. Alli, R.; Nguyen, P.; Geiger, T. Retrogenic modeling of experimental allergic encephalomyelitis associates T-cell frequency but not T-cell receptor functional affinity with pathogenicity. J. Immunol. 2008, 181, 136-145. [CrossRef]

120. Yu, D.; Rao, S.; Tsai, L.M.; Lee, S.K.; He, Y.; Sutcliffe, E.L.; Srivastava, M.; Linterman, M.; Zheng, L.; Simpson, N.; et al. The transcriptional repressor Bcl-6 directs $\mathrm{T}$ follicular helper cell lineage commitment. Immunity 2009, 31, 457-468. [CrossRef] 
121. Nurieva, R.I.; Chung, Y.; Martinez, G.J.; Yang, X.O.; Tanaka, S.; Matskevitch, T.D.; Wang, Y.; Dong, C. Bcl6 mediates the development of T follicular helper cells. Science 2009, 325, 1001-1005. [CrossRef]

122. Differentiation, H.C.; Action, C.; Cell-dependent, A.; Palmer, E.M.; Seventer, C. A Van Bcl6 and Blimp-1 are reciprocal and antagonistic regulators of $\mathrm{T}$ follicular helper cell differentiation. Science 2009, 325, 1006-1010. [CrossRef]

123. Choi, Y.S.; Kageyama, R.; Eto, D.; Escobar, T.C.; Johnston, R.J.; Monticelli, L.; Lao, C.; Crotty, S. ICOS receptor instructs $\mathrm{T}$ follicular helper cell versus effector cell differentiation via induction of the transcriptional repressor Bcl6. Immunity 2011, 34, 932-946. [CrossRef]

124. Fazilleau, N.; Mcheyzer-williams, L.J.; Rosen, H.; Mcheyzer, M.G. The function of follicular helper T cells is regulated by the strength of $\mathrm{T}$ cell antigen receptor binding. Nat. Immunol. 2009, 10, 375-384. [CrossRef] [PubMed]

125. Ditoro, D.; Winstead, C.; Pham, D.; Witte, S.; Andargachew, R.; Singer, J.R.; Wilson, C.G.; Zindl, C.L.; Luther, R.J.; Silberger, D.J.; et al. Differential IL-2 expression defines developmental fates of follicular versus nonfollicular helper T cells. Science 2018, 361. [CrossRef]

126. Ren, H.M.; Kolawole, E.M.; Ren, M.; Jin, G.; Netherby-Winslow, C.S.; Wade, Q.; Shwetank; Rahman, Z.S.M.; Evavold, B.D.; Lukacher, A.E. IL-21 from high-affinity CD4 T cells drives differentiation of brain-resident CD8 T cells during persistent viral infection. Sci. Immunol. 2020, 5, 1-12. [CrossRef] [PubMed]

127. Moran, A.E.; Hogquist, K. T-cell receptor affinity in thymic development. Immunology 2011, 135, $261-267$. [CrossRef] [PubMed]

128. Hsieh, C.; Zheng, Y.; Liang, Y.; Fontenot, J.D.; Rudensky, A.Y. An intersection between the self-reactive regulatory and nonregulatory $\mathrm{T}$ cell receptor repertoires. Nat. Immunol. 2006, 7, 401-410. [CrossRef]

129. Pacholczyk, R.; Kern, J. The T-cell receptor repertoire of regulatory T cells. Immunology 2008, 125, 450-458. [CrossRef]

130. Sprouse, M.L.; Bettini, M.L.; Bettini, M.; Sprouse, M.L.; Scavuzzo, M.A.; Blum, S.; Shevchenko, I.; Lee, T.; Makedonas, G.; Borowiak, M.; et al. High self-reactivity drives T-bet and potentiates Treg function in tissue-specific autoimmunity Find the latest version: High self-reactivity drives T-bet and potentiates treg function in tissue-specific autoimmunity. JCI Insight 2018, 3, 1-14. [CrossRef]

131. Frost, E.L.; Kersh, A.E.; Evavold, B.D.; Lukacher, A.E. Cutting edge: Resident memory CD8 T cells express high-affinity TCRs. J. Immunol. 2015, 195, 3520-3524. [CrossRef] [PubMed]

132. Su, L.F.; Kidd, B.A.; Han, A.; Kotzin, J.J.; Davis, M.M. Virus-specific CD4+ memory-phenotype T cells are abundant in unexposed adults. Immunity 2013, 38, 373-383. [CrossRef]

133. Mateus, J.; Grifoni, A.; Tarke, A.; Sidney, J.; Ramirez, S.I.; Dan, J.M.; Burger, Z.C.; Rawlings, S.A.; Smith, D.M.; Phillips, E.; et al. Selective and cross-reactive SARS-CoV-2 T cell epitopes in unexposed humans. Science 2020, 94, eabd3871. [CrossRef] [PubMed]

134. Le Bert, N.; Tan, A.T.; Kunasegaran, K.; Tham, C.Y.L.; Hafezi, M.; Chia, A.; Chng, M.H.Y.; Lin, M.; Tan, N.; Linster, M.; et al. SARS-CoV-2-specific T cell immunity in cases of COVID-19 and SARS, and uninfected controls. Nature 2020, 584, 457-462. [CrossRef] [PubMed]

135. Sette, A.; Crotty, S. Pre-existing immunity to SARS-CoV-2: The knowns and unknowns. Nat. Rev. Immunol. 2020, 20, 457-458. [CrossRef]

136. Grifoni, A.; Weiskopf, D.; Ramirez, S.I.; Mateus, J.; Dan, J.M.; Moderbacher, C.R.; Rawlings, S.A.; Sutherland, A.; Premkumar, L.; Jadi, R.S.; et al. Targets of T cell responses to SARS-CoV-2 coronavirus in humans with COVID-19 disease and unexposed individuals. Cell 2020, 181, 1489-1501. [CrossRef]

137. Weiskopf, D.; Schmitz, K.S.; Raadsen, M.P.; Grifoni, A.; Okba, N.M.A.; Endeman, H.; van den Akker, J.P.C.; Molenkamp, R.; Koopmans, M.P.G.; van Gorp, E.C.M.; et al. Phenotype and kinetics of SARS-CoV-2-specific T cells in COVID-19 patients with acute respiratory distress syndrome. Sci. Immunol. 2020, 5, 1-14. [CrossRef]

138. Cole, D.K.; Bulek, A.M.; Dolton, G.; Schauenberg, A.J.; Szomolay, B.; Rittase, W.; Trimby, A.; Jothikumar, P.; Fuller, A.; Skowera, A.; et al. Hotspot autoimmune T cell receptor binding underlies pathogen and insulin peptide cross-reactivity. J. Clin. Investig. 2016, 126, 2191-2204. [CrossRef]

139. Moore, T.; Wagner, C.R.; Scurti, G.M.; Hutchens, K.A.; Godellas, C.; Clark, A.L.; Kolawole, E.M.; Lance, M.; Singh, N.K.; Huyke, F.A.; et al. Clinical and immunologic evaluation of three metastatic melanoma patients treated with autologous melanoma-reactive TCR-transduced T cells. Cancer Immunol. Immunother. 2018, 67, 311-325. [CrossRef] 
140. Knudson, K.M.; Goplen, N.P.; Cunningham, C.A.; Daniels, M.A.; Teixeiro, E. Low-affinity T cells are programmed to maintain normal primary responses but are impaired in their recall to low-affinity ligands. Cell Rep. 2013, 4, 554-565. [CrossRef]

141. Sanecka, A.; Yoshida, N.; Kolawole, E.M.; Patel, H.; Evavold, B.D.; Frickel, E.-M. T cell receptor-major histocompatibility complex interaction strength defines trafficking and CD103+ memory status of CD8 T cells in the brain. Front. Immunol. 2018, 9, 1-15. [CrossRef]

Publisher's Note: MDPI stays neutral with regard to jurisdictional claims in published maps and institutional affiliations.

(C) 2020 by the authors. Licensee MDPI, Basel, Switzerland. This article is an open access article distributed under the terms and conditions of the Creative Commons Attribution (CC BY) license (http://creativecommons.org/licenses/by/4.0/). 